\title{
New town and village greens: the need for reform
}

\author{
by Morag Ellis
}

In December 2002 the Planning and Environmental Law Reform Working Group of the Society for Advanced Legal Studies published a paper entitled "New Town and Village Greens Proposals for Reform". It was prompted by the practical concerns of those of us in the group who are lucky enough to find ourselves practising in this curious area of law and by a desire to contribute to the debate on the general subject of common land and town and village greens (TVGs) initiated by Michael Meacher MP and DEFRA in 2000 (Consultation on Greater Protection and Better Management of Common Land in England and Wales, DEFRA, February 2000).

T his article considers the main conclusions of the SALS working group report "New Town and Village Greens - Proposals for Reform", and my aim in writing it is to set a historical and jurisprudential context for discussion of the following questions:

1. What are the nature, purpose and implications of the current provisions for registration of new TVGs?

2. Is it necessary and/or desirable to continue to register new TVGs?

3. If it is, how might the law and the system of registering new TVGs be clarified and improved?

4. Are the provisions for amendment of TVG registers adequate? If not, how might they be improved?

\section{HISTORY OF TVG LAW}

The background and nature of the Commons Registration Act 1965 ("the 1965 Act") were summarised in the judgment of Carnwath $\mathrm{J}$ (as he then was) in $R \mathrm{~V}$ Suffolk County Council, ex parte Steed (1995) 70 P\&CR 487 at 489-494. He noted that the Act was passed in response to some of the recommendations of the Jennings Report (1958) and that, as explained by the Minister, its "simple purpose" was to "create the machinery for establishing the facts by registration. ... Until the facts are recorded it would be premature to frame the further legislation that will be required"

Carnwath J also commented on the threefold definition of TVG in the Act :

(a) land which has been allotted by or under any Act for the exercise or recreation of the inhabitants of any locality;

(b) or on which the inhabitants of any locality have a customary right to indulge in lawful sports and pastimes; (c) or on which the inhabitants of any locality have indulged in such sports and pastimes as of right for not less than 20 years.

He observed that Class (c) "corresponds to the normal legal understanding of a TVG, as one whose status is derived from custom" (at p.491, referring to Hammerton v Honey (1876) 24 WR 603 in which Sir George Jessell MR said:

"There are certain rights which may be claimed by custom, as distinct from prescription. What is called a right of recreation and amusement, of air and exercise, or the playing of all manner of lawful games and pastimes, is a right in the nature of an easement which may well be claimed by custom," custom being "local law because it is the law of a particular place as distinguished form the general common law").

Class (c), however, he said, was novel, in that it treated 20 years use as conclusive, "whether or not there is evidence of a modern origin". "Unfortunately" he added "the Act does not indicate what legal consequences, if any, are to follow registration of such a 20-year-green." Other judges have noted this last point (see eg Re Turnworth Down [1978] Ch 251, 260-1 Oliver J; New Windsor Corporation v Mellor [1975] 1 Ch 380, Lord Denning MR: "I hope another statute will not be long delayed"; Corpus Christi College, Oxford v Gloucestershire CC [1983] 1 QB 360 at 378H, Oliver LJ: "This Act ... is crying out for amendment"). Carnwath J, referring to the economic and social implications of Steed, joined his voice to the chorus, expressing the wish:

"It may be that this case will help to underline the continuing need to address the problems arising from this legislative scheme, which was half begun 30 years ago, but never completed". 
Pill LJ in the Court of Appeal in Steed said:

"The central difficulty about construing the Act is in considering whether it was intended merely or primarily to provide a mechanism for registering rights or whether it has the potential to destroy existing rights and permit the creation of new rights"

That question did not fall to be determined, but Pill LJ considered it at length, stating:

"I find it difficult to conclude other than that Parliament intended, in section 22, to open the way to the creation of new rights... The land is a town green by virtue of statute and, once it is a town green, should bear the same incident as any other town green. It is the relevant use which, under statute, creates the right but once it is registered under section 13 , section 10 provides that registration shall be conclusive of the matters registered." (1996) 75 P\&CR 102 at 106 and 115).

The SALS paper explored some of the implications of this view and I shall return to them later in this article.

It must be in everyone's interests to resolve these issues before the Act reaches its fortieth anniversary in a couple of years' time. This is not simply due to a desire for legislative tidiness, but because the fundamental uncertainty about the nature of Class $\mathrm{C}$ rights is of great practical significance to landowners and communities. For example, there is no authority on the status of land in respect of which an application has been made but not yet determined. If the 1965 Act created no new rights and really was confined to regulating registration then a landowner will be able to defeat a claim by getting on and building in spite of the application. So far this proposition has not been tested, possibly because of fear of bad publicity and uncertainty on the part of developers. (Imagine investing heavily in starting to develop a site only to be faced by an interim injunction).

It is unclear whether or not building in these circumstances would constitute a criminal offence or a civil wrong or both and, in any event, whether it must be the local authority who brings the matter to court or whether local residents can. As we pointed out in the SALS paper, it is not even clear whether the regulatory legislation applies to Class $\mathrm{C}$ greens once registered.

The decision of the Court of Appeal in Steed was, of course, disapproved by the House of Lords in $R_{v}$ Oxfordshire County Council, ex parte Sunningwell Parish Council [1999] 3 WLR 160. In deciding that the words "as of right" in the Act meant nothing more than the familiar test for prescription (Nec vi, nec clam, nec precario: not by force, nor stealth, nor the licence of the owner), their Lordships emancipated Class $\mathrm{C}$ greens from the shackles of customary law to begin a life of their own, founded upon 20th century lifestyles - mobile, and focused upon the individual or his immediate family group, rather than a wider community. They have appeared in some surprising places :applications have been made in relation to, amongst other things, beaches, school playing fields, rugby pitches and woods - anywhere, apparently, that 20th century man walked his dog. They also left unanswered a number of difficult questions, some of which have already been considered in the spate of applications which followed the decision in Sunningwell and its widespread dissemination.

The impetus which this decision has given to the making of applications enhances the desirability of legislative clarification. Sunningwell was decided in late June 1999. One of the issues which was touched on but not fully considered in the speech of Lord Hoffmann was that of locality. Lord Hoffman said that he was "willing to assume, without deciding, that the user should be similar to that which would have established a custom", adding that he thought it "sufficient that the land is used predominantly by inhabitants of the village" (at pp172G-173A).

At the end of November 2000 the Countryside and Rights of Way Act ("CROW") was passed. Section 98 CROW amended the 1965 Act's definition of TVG to provide:

"(1A) Land falls within this subsection if it is land on which for not less than twenty years a significant number of the inhabitants of any locality or of any neighbourhood within a locality have indulged in lawful sports and pastimes as of right, and either-

(a) continue to do so, or

(b) have ceased to do so for not more than such period as may be prescribed, or determined in accordance with prescribed provisions.

(1B) If regulations made for the purposes of paragraph (b) of sub-section (1A) of this section provide for the period mentioned in that paragraph to come to an end unless prescribed steps are taken, the regulations may also require registration authorities to make available in accordance with the regulations, on payment of any prescribed fee, information relating to the taking of any such steps." (emphasis added)

The background to these amendments is set out in the SALS paper (at paras 1.4-1.7). It was also pointed out in the paper that the new legislative concepts might prove difficult to apply. "Significant number" has been held to refer to use signifying that the land is "in general use by the local community for informal recreation, rather than occasional use by individuals as trespassers" ( $R_{V}$ Staffordshire County Council, ex parte McAlpine Homes Ltd, 17 January 2002, per Sullivan J at para 71). This is helpful, but does not assist in the definition of "neighbourhood", a deliberately looser term than "locality" (an area known to law - see MoD v Wiltshire County Council (1995) Ch 931 at 937c) but which nevertheless still has to be "within a locality".

For this statutory requirement to have any meaning, there must be some functional and geographical link, but 
such a reading is difficult to reconcile with the advice in DETR Circular 04/2001 Countryside and Rights of Way Act 2000 (para 80), to the effect that: "the implications of this are that the commons registration authority will need to be satisfied only that a significant number of local inhabitants have used the land in a qualifying manner. Use by people not from the locality will therefore be irrelevant". That guidance is perhaps a pre-echo of the proposal in the Common Land Policy Statement 2002 (para 45) that:

"evidence of a clear pattern of public use of an area of land should suffice to qualify land for potential registration as a green, without a requirement to show (as at present) that it emanates predominantly from one specified locality or group".

The statements as to the law in the two documents, however, are inconsistent and highlight the current uncertainty.

Another difficulty about the amended definition is that it could lead to a situation where local users have been "significant" in the Staffordshire sense, but in the minority relative to the total number of users of the land, with the result (if the view were taken that registration of a Class $\mathrm{C}$ green does indeed confer rights - the central problem of the 1965 Act to which I have referred) that the minority could exclude the majority. This is clearly not the Government's wish. The policy statement says: "We shall ... look to ensure that the general public has a right of access to all greens once they have been established" (para 51).

Such policy aspirations are entirely understandable, but it should be noted how far we are now straying from the concept of particular, exclusive rights based on local custom. The piecemeal approach is inherently problematic because, as Carnwath J said in Steed, one must keep in mind that the statutory test is a single one and that its individual elements "take colour" from each other. The separate treatment of parts of the test in Sunningwell and the CROW amendment raises as many anomalies and questions as it answers. The SALS paper concluded (at para 1.11):
"It seems to us that there are two main reasons for the difficulties and lack of certainty surrounding the law. These are firstly the incomplete and piecemeal nature of the legislation and secondly the problems of trying to apply an antiquated form of land use control in our contemporary society. The attempt to tackle the first merely throws into clearer relief the second."

While on the subject of piecemeal changes, the CROW amendment has left hanging in mid air the question of interruptions and the relevant date for determination. More than two years have gone by since the CROW amendment and no regulations have been made. It is quite clear from the consultation paper and Hansard that the objective was to make it easier for local people to prepare a case for registration. Under the legislation as it now stands there is at least a strong argument that the position for applicants is actually worse because of the requirement for continuing user.

\section{REFORM}

We can probably all agree both that reform is necessary and, in the words of the foreword to the Common Land Policy Statement, that "this is an extremely complex policy area to deal with and there is no 'quick fix'." Thereafter, it may be that opinions will divide and the choices to be made about reform will ultimately be political ones.

We in the SALS Group, approaching the topic initially via the route of the promised regulations pursuant to the CROW amendment, found that the more we thought about the system of new TVG registration the more anomalous it appeared. It was obvious that the central uncertainty about the effect of registration should be resolved, but considering this led to questions about the relationship of the qualifying evidence of user (both geographical and the nature of lawful sports and pastimes) to the effect of the resultant registration which were not easily resolved. It seemed anomalous, for example, that evidence of dog walking and bird watching by some inhabitants might found a right for other inhabitants to indulge in fox hunting over the land. Likewise, that while the parish church would have a clear entitlement to use land for activities, a "gathered church" of a non-Established denomination or religion, with a building in the neighbourhood, but drawing people form a wide area, might not. Bearing in mind that, on the face of it, criminal liability might attach to infringements of local rights, the situation seemed anachronistic and unsatisfactory.

In addition, the registration process itself gives rise to expense, delay and uncertainty for all involved, (thought it must be admitted that it is often very enjoyable to take part in the inevitable public inquiries). Many applications are made once the town and country planning process has run its course, perhaps through many stages, after considerable private and public investment. An application is made as the last resort by the locals to prevent development to which they object, but which has been decided under town and country planning legislation to be in the public interest. A successful application will probably frustrate such a project, whereas even one which fails might delay permitted development for two or three years or more. Taking all this into account, along with the anachronisms of the law itself, the group concluded (at para 1.11):

"We have come to the unanimous view that there is no justification for retaining the procedure. The interests of communities in open space and recreation are adequately protected by the planning system which, being a modern, comprehensive statutory code, is better suited to achieving outcomes which are in the public interest." 
TVG's should be defined for all purposes simply as "land which has been registered as such". Awkward questions about the status of land in respect of which there had been the requisite use but no registration could no longer arise. Under the current law, as we have seen, this is an untested question of some significance both to would-be developers and local inhabitants. Our proposed definition would also resolve some of the doubts about the applicability of old regulatory legislation to Class $\mathrm{C}$ greens.

Since the Government in its policy documents states that user by the public should become relevant to registration and be secured by it, seemingly the policy justification is not based on anything intrinsic to TVG rights, rather on general public open space grounds. If the proposals in the Common Land Policy Statement were enacted, Class C TVGs would, essentially, be public open space rather than areas of land subject to a particular local custom which is "certain and reasonable" (per Sir George Jessel MR in Hammerton $v$ Honey and held to apply to Class $\mathrm{C}$ greens by Pill LJ in Steed (CA) at p111).

In the event that the system of registering "new" TVGs were to be kept, the SALS Paper suggested a number of reforms, some of which would tidy up procedural uncertainties, such as the amendment of applications and a power for registration authorities to reject an application which is obviously hopeless on the merits without going through all the statutory procedures of advertisement and consultation.

In an attempt to strike a reasonable balance between the need for local people to have time to prepare an application and the need for landowners and others to achieve certainty about the status of land before investing time and money in its development, we suggested a new procedure. It would work as follows. A landowner desiring to flush out any potential TVG application could erect notices on the land asserting that it is not a TVG and either banning entry or permitting it for the time being. There would then be a period within which any other person could serve notice on the Registration Authority indicating provisional objection to the landowner's notice. Time would be "frozen" for a period to enable the locals to obtain advice/gather evidence with a view to deciding whether or not to make an application (see the SALS report, paras 3.5-3.10 for full details including suggested statutory wordings).

The other area which we suggested needed consideration was that of de-registration. There is no provision for de-registration as such unless the land ceases to be TVG. The 1965 Act does not define the circumstances in which land can cease to be TVG, although such a result is contemplated in other legislation. It is therefore unclear whether cessation is confined to those statutory instances or whether it can come about by other means, such as long cessation of use or incompatible intervening events. This uncertainty both in its own right and coupled with that surrounding the relevant date of assessment for registration purposes, is a further real difficulty. (For example, it might be held, in the absence of the new regulations, that the relevant date was that of the application, but in the meantime, in advance of any inquiry or court ruling, an owner could have built on the land or invited user by the general public. Would he, in the event of a registration being made, be entitled to an immediate amendment?)

Some provision should be made for de-registration in limited circumstances, perhaps along the lines of the Common Land Policy Statement proposal for commons: "small isolated pockets of common no longer of much use or value to anyone, and preserving some scope for putting land to better public use in future in circumstances where land exchange or compulsory purchase orders might not be possible or appropriate" (see para 8).

There is another procedural issue which deserves consideration. It has become a widespread practice to hold a non-statutory inquiry before an independent person, usually a barrister, who then reports to the registration authority. Given that the number of barristers who specialise in this area is fairly small, it is not unusual for one of them to be sitting as "inspector" on one case, then appearing as advocate in another. Apart from the fact that there is the scope for conflicting decisions, these changes of role can be awkward. If the system is to remain, it has been suggested that there may be a case for appointing TVG "commissioners" or asking the Planning Inspectorate to undertake the inquisitorial role whether on behalf of registration authorities and reporting to them or having jurisdiction themselves to determine applications.

\section{Morag Ellis}

Barrister

The report New Town and Village Greens - Proposals for Law Reform was prepared by a sub-group of the SALS Planning and Environmental Law Reform Working Group chaired by the author. 